CURRENT RESEARCH JOURNAL OF HISTORY

(ISSN -2767-472X)

VOLUME 03 ISSUE 01 Pages: 10-13

SJIF IMPACT FACTOR (2021: 5. 505)

OCLC - 1243560778 METADATA IF - 6.458

Crossref do

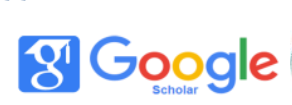

10

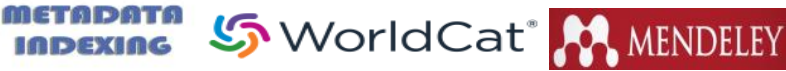

Publisher: Master Journals

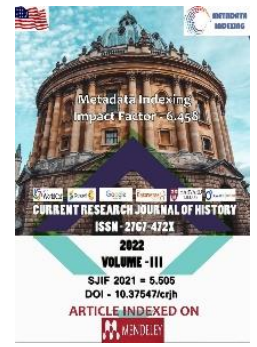

Journal Website: https://masterjournals. com/index.php/crih

Copyright: Original content from this work may be used under the terms of the creative commons attributes 4.0 licence.
Research Article

\section{CHANGES IN AGRICULTURE IN THE FERGANA REGION DURING THE RULE OF THE GOVERNOR GENERAL OF TURKESTAN}

Submission Date: December 26, 2021, Accepted Date: January 06, 2022, Published Date: January 16, 2022

Crossref doi: https://doi.org/10.37547/history-crih-03-01-03

Abdulkhodi Khaydarov

Researcher, National University of Uzbekistan, Tashkent, Uzbekistan

\title{
ABSTRACT
}

This article discusses changes in agriculture in the Fergana region during the rule of the Governor General of Turkestan. The core of the Fergana region, which was established in 1876 as part of the Governor-General of Turkestan, was the Fergana Valley. The Fergana Valley has also attracted the attention of government circles and many researchers as the Russian Empire tries to take full advantage of Central Asia's potential. Because here there is a rich tradition of tillage, cultivation of grain crops, their storage and processing, many things. These processes played an important role in the daily life of agriculture in the valley, and the natural and geographical conditions facilitated the development of agriculture. Therefore, Russian researchers have collected and analyzed data on the natural and geographical conditions of the Fergana Valley in the development of agriculture in the country, the economic activities of the population of the valley, in particular, farming and animal husbandry.

\section{KEYWORDS}

Governor General of Turkestan, Fergana region, farming and animal husbandry.

\section{INTRODUCTION}

In particular, in the 1980s, A.F. Middendorf conducted his own research on the Fergana Valley. In his work
"Essays on the Fergana Valley" he said that "the basis of success in agriculture is the experience of the local 
CURRENT RESEARCH JOURNAL OF HISTORY

(ISSN -2767-472X)

VOLUME 03 ISSUE 01 Pages: 10-13

SJIF IMPACT FACTOR (2021: 5. 505)

OCLC - 1243560778 METADATA IF - 6.458

Crossref do

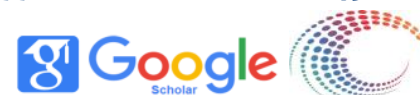

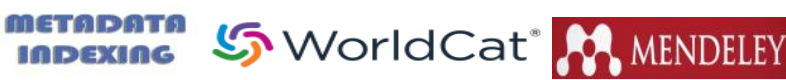

Publisher: Master Journals

population"[1], admitted. The administration of the Governor-General of Turkestan also considers the Fergana Valley as an area of great potential for the development of agriculture, horticulture, melons, especially cotton.

According to official data of 1896 , the volume of arable land in Fergana region was 949,399 desiatins of 450 sq. $\mathrm{Km}$. formed the sajen[2]. Of these, artificially irrigated lands are 717444 desiatina 1335 sq. Km. sajenni, while the protected lands are 231,954 desyatina $1515 \mathrm{sq} . \mathrm{km}$. formed the sajen. Protected lands are lands where a certain part of arable land is not available for permanent artificial irrigation. The following year, this part of the land was rested and the other part was cultivated. Therefore, these lands are divided into several parts depending on the amount of water used for irrigation. 882,717 acres of land 450 sq. Km. 18,857 desiatins to the population, 28,900 desiatins to the cities, and 18,925 desiatins to the treasury[3].

At the end of the 19th century, as the population increased and the population was relocated from different parts of the empire, the demand for arable land also increased. As a result, by 1904, the volume of artificially irrigated land was 839,300 desiatins[4]. This was 121,856 desiatins more than in 1896. Due to land shortages in the Fergana Valley, this has been achieved mainly by improving the irrigation system in the reserve lands.

\section{THE MAIN RESULTS AND FINDINGS}

In agriculture, the main crops are wheat, rice, oats, barley, millet, potatoes and other food products. Wheat cultivation is subdivided into fall wheat and spring or dry wheat, respectively, and is grown by both sedentary and nomadic populations. In particular, in $1896,6,538,208$ pounds of spring wheat were grown by the settled population and 372,000 pounds by the nomadic population for a total of $6,910,208$ pounds[5]. 2373952 poods of spring or lalmi type of wheat were grown by the settled population and 386050 poods by the nomadic population for a total of 2760002 poods[6]. This shows that the nomadic population, along with the settled population, was actively involved in the cultivation of cereals.

At the same time, this year's report acknowledged that the volume of food produced was 717,568 pounds more than in 1895[7]. In addition to cereals, the production of cotton, alfalfa, tobacco, vegetables and various root crops was also high. Cultivated alfalfa was mainly used as fodder for horses. Although tobacco is mainly consumed by the local population, some of it has also been exported to Kashgar. Flax and sesame were mainly used to make oil. Melons, watermelons, cucumbers, cabbage, carrots, beets, potatoes and radishes are grown from vegetables.

The resettlement of the population to the Fergana Valley from different parts of the empire also had an impact on the type and volume of agricultural products grown here. In particular, by 1904 it can be seen that the area under crops such as millet, rice, peas, potatoes, hemp, sunflower has increased significantly.

Due to the favorable climate and soil conditions, apricots, peaches, pears, pomegranates, cherries, cherries, plums, beech, walnuts, almonds, grapes were grown in large quantities in Fergana region at that time. However, the local administration notes that the population's ignorance of ways to improve the sector hinders the development of horticulture[8].

In 1896 , the vineyards were 6,400 acres, of which $1,382,000$ pounds of grapes were grown. Very few of the grapes grown have been sent for processing for wine and alcohol, and the rest have been shown to be prepared for consumption in the form of fruits and 
CURRENT RESEARCH JOURNAL OF HISTORY

(ISSN -2767-472X)

VOLUME 03 ISSUE 01 Pages: 10-13

SJIF IMPACT FACTOR (2021: 5. 505)

OCLC - 1243560778 METADATA IF - 6.458

Crossref do

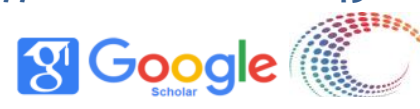
metadata (5. WorldCat

Publisher: Master Journals

raisins. More land was allocated for viticulture, mainly in Margilan, Kokand and Namangan districts, and high yields were obtained. In Andijan district, 285 desiatins of land were allocated for viticulture, from which 68,700 pounds were harvested. The yield of grapes in Andijan was 241 poods per 1 desiat, which was 119 poods in Margilan district, 158 poods in Kokand district, 324 poods in Namangan district and 49.6 poods in Osh district[9]. At the same time, only grapes grown in Namangan and Andijan districts were sent for processing for wine. The rest of the districts did not pay attention to it or did not cultivate grape varieties suitable for winemaking. At the same time, the imperial administration of the country noted that winemaking is a very new industry for the Fergana region[10].

Cotton growing has played a key role in the agriculture of Fergana region, and during the governor's term the volume of cotton production has increased from year to year. In 1896, the cotton area was 128,716 decimetres, 19,025 decimetres more than in 1895. The cotton crop was $6,609,000$ pounds, 1,155,000 pounds more than last year[11]. At the same time, the area under American cotton is growing every year. In particular, by 1904, the area under American cotton was 173,856 tenths, and the area under local cotton was 13,242 tenths[12].

The American variety of cotton grown is processed in ginneries. In 1896, their number was 16 in Margilan district, 14 in Kokand district, 24 in Namangan district, 15 in Andijan district, a total of 69 in the region. By this time, the local cotton variety had hardly gone to ginneries and was processed mainly by hand for the needs of the population.

If the average price of unprocessed cotton is 2 rubles 20 tiyn, this year the population of Fergana region received more than 13 million rubles from the cultivation of cotton[13]. But it should also be remembered that these funds came at the expense of enormous hardships.

About $1 / 3$ of the fiber was obtained from unprocessed cotton, and in $18962,200,000$ pounds of fiber were produced. If the average price of fiber is 7 rubles and 50 tiyins, traders and cotton processing plants earn more than 2,000,000 rubles[14]. This will give a big impetus to the expansion of cotton-growing areas in the region and the rapid growth of ginneries. As a result, cotton growing has become a leading sector in agriculture. By 1904, the area of artificially irrigated arable land had reached 186,828 tenths, which was $31 \%$ of the total arable land.

In 1903, due to favorable weather conditions, a high yield of cotton was obtained, which in turn led to a significant increase in income from cotton growing. At the same time, the price of cotton increased from year to year, and in 1903 the price of 1 pound of cotton reached 4 rubles 80 tiyn[15]. As a result, the area under cotton in 1904 increased by 24\% compared to 1903.

Most of the agricultural products are sold. These products not only meet domestic needs but also supply foreign markets. One of the researchers of that period, A.P. Khoroshkhin, noted that cotton, fruits, wool, leather, silk and other agricultural products grown in the Fergana Valley were delivered to Tashkent and from there through Kokand, Andijan and other major cities. These proceeds were used to purchase goods needed for basic necessities. In particular, the sources say that Russian products, sugar and Indian tea were delivered to the valley from Tashkent and Bukhara.

\section{CONCLUSION}

In short, agriculture in the Fergana Valley has long been developed as a major industry. Although limited water resources and the difficult situation in the region have 
affected agriculture, biodiversity, new agro-systems and traditional farming have played a major role in the lives of the population. In addition, by the end of the 19th century, they had to adapt to the new political system and the resulting market relations. These processes are particularly noticeable in cereals, melons and cotton. The increase in cotton production, in turn, will lead to the emergence of factories and the widespread involvement of the majority of the population in commodity-money relations.

\section{REFERENCES}

1. Urakov, D. J., \& Otarbayeva, G. (2021). FROM THE HISTORY OF UYGHUR MIGRATION TO THE TERRITORIES OF THE GOVERNOR-GENERAL OF TURKESTAN. CURRENT RESEARCH JOURNAL OF HISTORY (2767-472X), 2(11), 25-31.

2. Jamoliddinovich, U. D. (2020). Conflict Of Interests Of Major Empires In Central Asia In The Middle Of The Xix Century. International Journal of Scientific and Technology Research, 9(5), 18-22.

3. Ураков, Д. Ж. (2005). Официальные отчеты российской администрации в Туркестане как исторический источник:(конец XIX-начало XX вв.).

4. Ураков, Д. Ж. Из истории формирования Центральноазиатских границ Российской империи («Памирский вопрос»).

5. У Ураков, А.Д. (2017). АНГЛО-РУССКАЯ БОРЬБА ЗА ПАМИР И УСТАНОВЛЕНИЕ ЗДЕСЬ ВЛАСТИ РОССИЙСКОЙ ИМПЕРИИ. Theoretical \& Applied Science, (1), 43-47.

6. Middendorf A.F. Essays on the Fergana Valley ... - p. 186.

7. Overview of the Fergana region for 1896. - New Margelan: Printing house of the Fergana regional government, 1898. - p.2
8. Overview of the Fergana region for 1896. - New Margelan: Printing house of the Fergana regional government, 1898. - p.3.

9. Overview of the Fergana region for 1904. - New Margelan: Printing house of the Fergana regional government, 1905. - P.15.

10. Overview of the Fergana region for 1896. - New Margelan: Printing house of the Fergana regional government, 1898. - P.4.

11. Overview of the Fergana region for 1896. - New Margelan: Printing house of the Fergana regional government, 1898. - P.4.

12. Overview of the Fergana region for 1896. - New Margelan: Printing house of the Fergana regional government, 1898. - P.4.

13. Overview of the Fergana region for 1896. - New Margelan: Printing house of the Fergana regional government, 1898. - P.5.

14. Overview of the Fergana region for 1896. - New Margelan: Printing house of the Fergana regional government, 1898. - P.5.

15. Overview of the Fergana region for 1896. - New Margelan: Printing house of the Fergana regional government, 1898. - P.5.

16. Overview of the Fergana region for 1896. - New Margelan: Printing house of the Fergana regional government, 1898. - P.6.

17. Overview of the Fergana region for 1896. - New Margelan: Printing house of the Fergana regional government, 1898. - P.16.

18. Overview of the Fergana region for 1896. - New Margelan: Printing house of the Fergana regional government, 1898. - P.8.

19. Overview of the Fergana region for 1896. - New Margelan: Printing house of the Fergana regional government, 1898. - P.8.

20. Overview of the Fergana region for 1896. - New Margelan: Printing house of the Fergana regional government, 1898. - P.18. 